
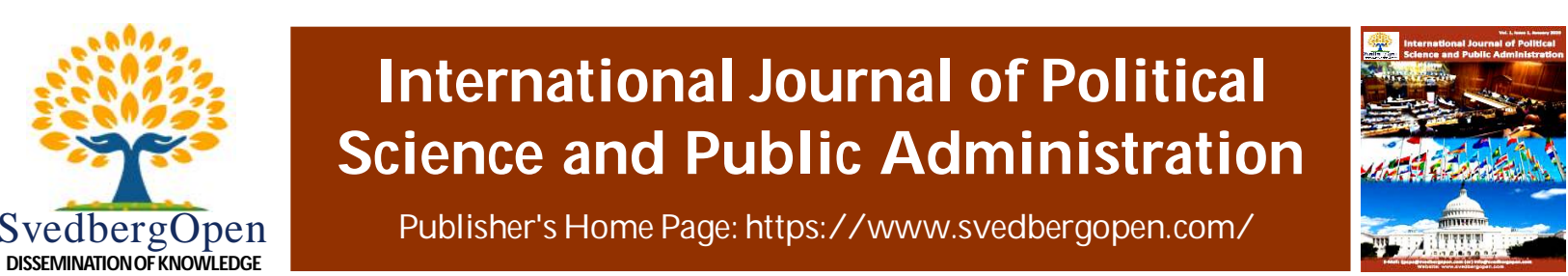

Research Paper

Open A ccess

\title{
Political Perspective on the Proposed Federal System of Government of Local Government Officials in SAMARICA, Occidental Mindoro
}

\author{
Melchor Padilla Dioso ${ }^{1 *}$, and Wenceslao M. Paguia ${ }^{2}$ \\ ${ }^{1}$ Faculty, Occidental Mindoro State College, San Jose, Occidental Mindoro, Philippines. E-mail: melchordioso@live.com \\ ${ }^{2}$ Faculty Occidental Mindoro State College, San Jose, Occidental Mindoro, Philippines. E-mail: junpaguia7@gmail.com
}

\section{Article Info}

Volume 1, Issue 2, September 2021

Received : 19 January 2021

Accepted : 04 July 2021

Published : 05 September 2021

doi: 10.51483/IJPSPA.1.2.2021.1-12

\begin{abstract}
In 1986, the Filipino people made history by overthrowing the 13-year Marcos dictatorship through a peaceful people power revolution. As a result, the country restored democracy and free elections through the 1987 Constitution which promised to empower citizens and Local Government Units (LGUs). Decentralization and local autonomy were further enhanced to put greater freedom and autonomous powers to local governments. However, it was the shortcomings of decentralization that paved the way for the interest of conversion to federalism. Thus, the present administration of the Philippine government has planned to convert the country's political system from democratic to federal. The study employed descriptive research design. The 58 local government officials in SAMARICA area were purposively selected. It includes the municipality of San Jose, Magsaysay, Rizal, and Calintaan in the province of Occidental Mindoro. The instrument underwent validity procedures and in the reliability test, it was found reliable. Result shows that the local government officials are middle-aged, male, and college graduate. In addition, they are the only politician in the family, members of the Liberal party, and councilors serving in the third class municipalities with short political experience. Lastly, officials have been attending seminars and trainings in the national level with few membership in organizations. The officials are "moderately perceptive" about the issues surrounding the proposed federal system of government. There is a significant difference in the respondents' perspectives when they are grouped based on age, the class of municipality, position, and attended seminars and trainings.
\end{abstract}

Keywords: Political perspective, Local government officials, Federalism, Charter change, Public administration

() 2021 Melchor Padilla Dioso and Wenceslao M. Paguia. This is an open access article under the CC BY license (https://creativecommons.org/licenses/by/4.0/), which permits unrestricted use, distribution, and reproduction in any medium, provided you give appropriate credit to the original author(s) and the source, provide a link to the Creative Commons license, and indicate if changes were made.

\section{Introduction}

On January 22 to 25,1986 , the Filipino people made history by overthrowing the 13-year Marcos dictatorship through a peaceful people power revolution. As a result, the country restored democracy and free elections through the 1987 Constitution which promised to empower citizens and Local Government Units (LGUs). Decentralization and local autonomy were further enhanced to put greater freedom and autonomous powers to local governments through the Local Government Code of 1991 in accordance with the provision stipulated in the said Constitution (Brillantes, 2016).

\footnotetext{
* Corresponding author: Melchor Padilla Dioso, Faculty, Occidental Mindoro State College, San Jose, Occidental Mindoro, Philippines.. E-mail: melchordioso@live.com
} 
However, Brillantes (2016) added that it was the shortcomings of decentralization that paved the way for the interest of conversion to federalism. As stated by Balisacan et al. (2006), over the past 25 years, decentralization has not delivered what some of its proponents might have expected: a decisive shift of power and resources out of the center, a vibrant, efficient and responsive system of local government, and a general shift in the quality of governance through the competitive "voice and exit" accountability mechanisms. Although it doesn't mean that decentralization has failed because there are local governments who have performed well even those outside Luzon. Still, this prompted former Senator Aquilino Pimentel, father of the Local Government Code, and even President Rodrigo Duterte to consider Federalization as an alternative strategy for regional and national development for the Philippines.

The increasing interest in Federalism from around the country can be traced as early as the 1980s advocated by PDPLaban. According to Abueva (2005), the proposed Federal Republic, or Federalism is based on the so-called principle of "dual sovereignty". It means that governmental powers, authority, responsibilities, and resources are distributed, and some of them also shared, between the Federal Government and the Autonomous States and their local governments.

The concept of local governments as self-reliant communities and effective partners in national and social progress has been put into test. For instance, powers continued to be concentrated in the National Capital Region (NCR) especially in Manila where the central government is located. Thirty-eight percent (38\%) or 1/3 of the country's Gross Domestic Product (GDP) comes from the NCR alone even though it has the lowest regional poverty incidence at 3.9\% (PSA, 2015). Still, development efforts were largely concentrated in Luzon at the expense of Visayas and Mindanao (Miral, 2017). On the contrary, the Autonomous Region of Muslim Mindanao (ARMM) which has the highest poverty incidence of 53.7\% ironically has the lowest GDP share of $0.7 \%$ as of 2015 . ARMM also does not get the full amount of its revenue share (70\% revenue share) because large taxpayers doing businesses in ARMM, in particular, file consolidated tax returns and pay taxes through their head offices in NCR. Unfortunately, these inequalities led in social unrest, with various groups (especially in Mindanao) arming themselves to fight against the system and the government (Malaya, 2017).

Malaya (2017) argued that the unequal distribution of public funds to the regions is one of the major causes of underdevelopment in the country. In the current system wherein almost $80 \%$ of the national government revenue is controlled by the national government and the rest are allocated to local governments, this limitation practically left LGUs with almost nothing for their local development. This has resulted in the Local Government Units (LGUs) being beholden to the central government (Adamat, 2016).

There is a need to win the hearts of Filipinos especially those serving as local government officials. According to the survey conducted by Social Weather Station (SWS) on March 23-27, 2018, the majority of Filipino adults remain unaware $(75 \%)$ of the Federal system. Furthermore, only five out of the proposed 18 regions were ready for the shift to a federal system of government according to the local government officials, including Metro Manila and CALABARZON, as a result of many issues surrounding federalization (Manahan, 2018).

According to Brillantes (2016), if there would be major lessons that the country has learned for the past 25 years, decentralization offered positive effects such as strong leadership at the local level, wider participation, and engagement with civil society institutions. However, there are still emerging issues and questions such as inadequate local finance, weak local - and national - capacity, or unclear and inadequate corporate and taxing powers of local governments. With that, given the Philippine context, and given our experience over the past quarter of a century, proponents believe that a federal system is more hospitable as an enabler of deepening local autonomy for local governments. In this regard, the researcher conducted this study which in the end would hopefully contribute in formulating the salient features of the proposed federal system of our government.

\section{Statement of the Problem}

The 1987 Constitution promised positive features that empower both citizens and the Local Government Units. However, decades after its realization, problems and issues still arise, such as, unequal distribution of wealth among regions. As a solution, the present administration is offering for a shift from a Presidential Unitary System to a Federal system. That is why generally, this paper sought to determine the political perspective of local government officials with the proposed federal system of the Philippine government in SAMARICAArea, Occidental Mindoro.

Specifically, this study aimed to answer the following questions:

1. What is the political characteristics of the respondents in terms of:
a. Age;
b. Sex;
c. Level of education; 
d. Number of politicians in the family;

e. Political party affiliation;

f. Class of municipality;

g. Position; and

h. Length of service;

2. What is the political perspective of local government officials with the proposed federal system of the Philippine government in terms of:
a. Age;
a. Political issues;
b. Economic issues; and
c. Social issues?

3. Is there a significant difference between the political perspectives of local government officials with the proposed federal system of the Philippine government when respondents are grouped according to their professional characteristics?

\section{Methodology}

\subsection{The Locale of the Study}

This study was conducted between October - March 2019, at the second district of Occidental Mindoro province which includes municipalities of San Jose, Magsaysay, Rizal, and Calintaan (SAMARICA).

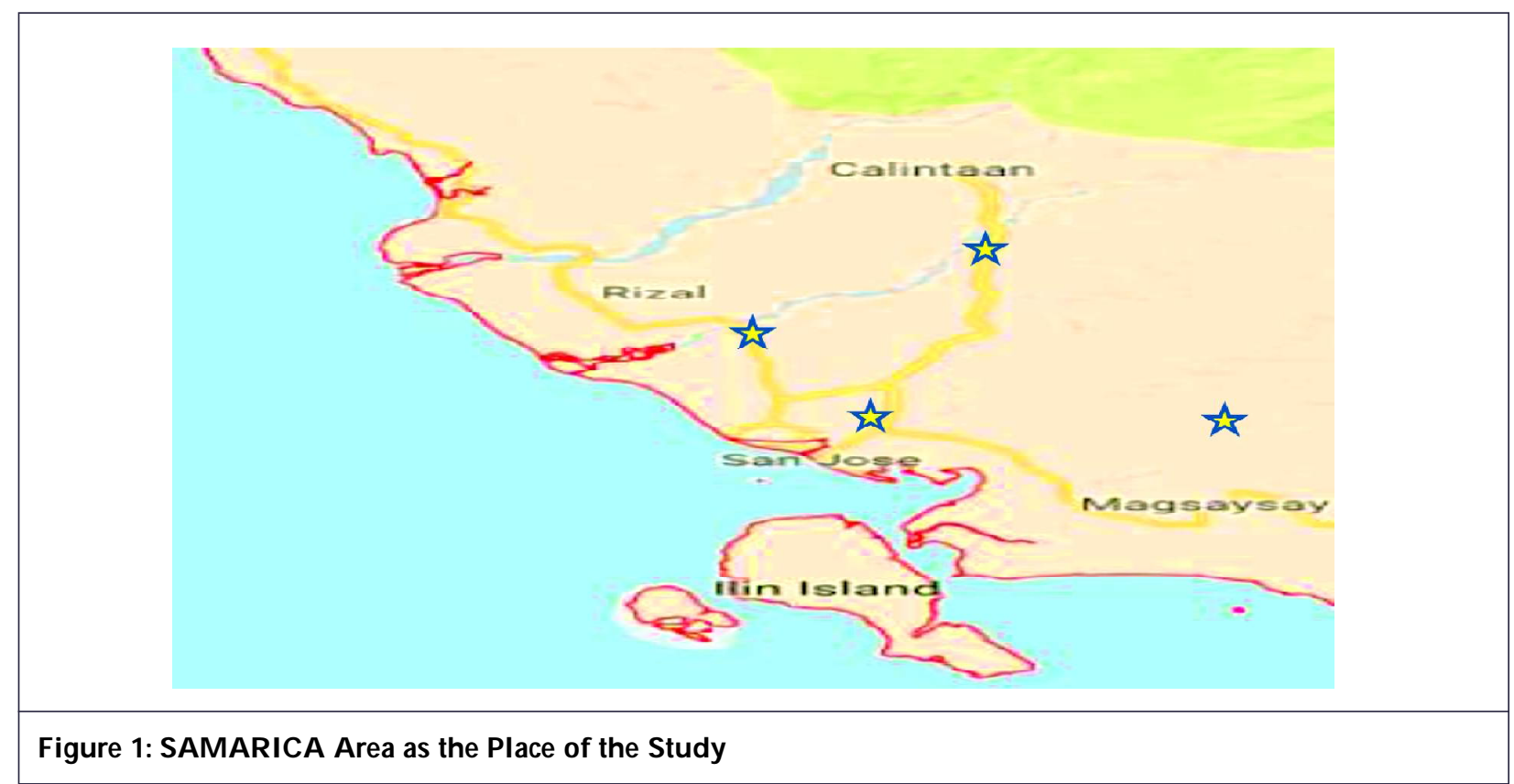

\subsection{Research Design}

This study is quantitative utilizing the descriptive-comparative research design. This study is descriptive because this study aimed to identify the professional characteristics of the respondents and political perspective with respect to the proposed Federal system of Government. This is comparative because this study determined the difference between the political perspectives of respondents when grouped according to their political characteristics.

\subsection{Respondents of the Study}

The respondents were selected using purposive sampling. They are the 58 local government officials in SAMARICA Area, Occidental Mindoro which includes the municipality of San Jose, Magsaysay, Rizal, and Calintaan in the province of Occidental Mindoro. Local government officials include the Mayor, the Vice-Mayor, members of Sangguniang Bayan (SB), and presidents of the Ligang Barangay (LnB), presidents of the Sangguniang Kabataan, and Barangay Captains who served for not less than two terms. 


\subsection{Data Gathering Procedure}

In gathering data, permission to conduct the study was safeguarded first. After the approval, a letter of request to distribute questionnaires was sent to the Mayor's Office of the municipalities. Then, questionnaires were distributed to the SB members and another set of respondents. The respondents were requested to answer the questionnaires during their available time. The data were collected, tabulated and analyzed with the help of a statistician using Microsoft Excel and Statistical Package for Social Sciences (SPSS).

\subsection{Research Instrument}

A self-constructed survey-questionnaire consisting of 2 sections was employed in this study. The first section includes questions with reference to the professional characteristics of respondents. The second part has a total of 21 items consisting of 5 items per parameter for the political perspective of local government officials with the proposed federal system of Government.

The items included for political perspective were derived by reviewing the literature and legal documents, specifically from the "Salient Features of the Proposed Draft Constitution of the Federal Republic of the Philippines on the Form and Structure of Government, States and Local Governance" submitted at the Committee on Constitutional Amendments, Sub Committee 1 on the Review of Articles VI, VII and X of the 1987 Constitution. The researcher also based some of the items in the questionnaire from the research paper of Jecy F Duron, entitled "Federalism: An Alternative System of Government for the Philippines".

Each item was rated using 4-point Likert scale ranging from "strongly disagree (1) to strongly agree (4)" for political perspective. 4-point Likert scale has been used by some researchers because there is no neutral option. According to Chaudhary (2012), this is done in order to extract a specific response from the respondents.

The instrument underwent validity procedures. It was shown to five experts for content and face validity. Their comments and suggestions were considered for the final draft of the survey questionnaire. It was then tried out to seven barangay captains, one SK Federation President, and two councilors. It was found out that the instrument was reliable with Cronbach's alpha of 0.908 (ranging from 0.902 to 0.913 ).

\subsection{Data Analysis}

The following statistical tools and treatments were used in this study:

1. To determine the political characteristics of respondents and political perspective, descriptive statistics such as mean and frequency, and percentage were used.

2. To determine the difference between the political perspective when respondents are grouped according to political characteristics, Independent samples T-test and ANOVA were used.

\section{Results and Discussion}

\subsection{Political Characteristics of the Respondents}

Table 1 presents the political characteristics of the local government officials of SAMARICA area in Occidental Mindoro.

Table 1: Percentage and Frequency Distribution of Respondents

\begin{tabular}{|l|c|c|}
\hline Respondents & Frequency & Percentage \\
\hline Mayor & 2 & 3.4 \\
\hline Vice-Mayor & 3 & 5.3 \\
\hline SB Members & 7 & 46.6 \\
\hline LnB President & 4 & 6.9 \\
\hline SK Federation President & 2 & 3.4 \\
\hline Barangay Captains & 20 & 34 \\
\hline Total & $\mathbf{5 8}$ & $\mathbf{1 0 0 \%}$ \\
\hline
\end{tabular}


In terms of age, the mean is 50.91 with a range of $20-72$. The majority of them has an age of $36-55$ which is $68.9 \%$ of the total number of respondents, followed by 56 years old and above which is $19 \%$ and the least are 20-35 years old which comprises $12.1 \%$ of the respondents. This implies that the majority of our local government elected officials are middle-aged. Not only in the Philippines, but politicians age in Europe and US are also usually in the same age range. In the US, the average age of current members of the House of Representatives is 57 years, while local government officials are 50 years (Alesina et al., 2015).

In terms of sex, a large portion, consisting of $89.7 \%$ of the total population is male while the rest is female (10.3\%). This indicates that men are more engaged in politics than women. This is also supported by the study of Kurtbas (2015) that women have not become politicized not only because of lower political interest but also because there is a wellrooted/practical socio-political culture in the society which asserts that politics is a "man's job".

\begin{tabular}{|c|c|c|}
\hline Indicators & Frequency $(\mathbf{n}=\mathbf{5 8})$ & Percentage \\
\hline \multicolumn{3}{|l|}{ Age } \\
\hline $20-35$ & 7 & 12.1 \\
\hline $36-55$ & 40 & 68.9 \\
\hline 56 years old and above & 11 & 19 \\
\hline Mean: 50.91 & Range: 20 - 72 & \\
\hline \multicolumn{3}{|l|}{$\operatorname{Sex}$} \\
\hline Male & 52 & 89.7 \\
\hline Female & 6 & 10.3 \\
\hline \multicolumn{3}{|l|}{ Level of Education } \\
\hline Primary & 2 & 3.4 \\
\hline Secondary & 11 & 19 \\
\hline Tertiary & 45 & 77.6 \\
\hline \multicolumn{3}{|c|}{ Number of politicians in the family } \\
\hline 1 & 32 & 55.2 \\
\hline 2 & 21 & 36.2 \\
\hline 3 & 5 & 8.6 \\
\hline Mean: 1.58 & Range: 1 - 3 & \\
\hline \multicolumn{3}{|c|}{ Political party affiliation } \\
\hline PDP - Laban & 6 & 10.3 \\
\hline Liberal Party & 16 & 27.6 \\
\hline Independent & 5 & 8.6 \\
\hline Others & 5 & 8.6 \\
\hline None & 26 & 44.8 \\
\hline \multicolumn{3}{|l|}{ Class } \\
\hline First & 15 & 25.9 \\
\hline
\end{tabular}




\begin{tabular}{|l|c|c|}
\hline Table 2 (Cont.) & Frequency (n = 58) & Percentage \\
\hline Indicators & 43 & 74.1 \\
\hline Third & 2 & 3.4 \\
\hline Position & 3 & 5.2 \\
\hline Mayor & 27 & 46.6 \\
\hline Vice Mayor & 4 & 6.9 \\
\hline Councilor & 2 & 3.4 \\
\hline LnB President & 20 & 34.5 \\
\hline SK Federation President & Range: $3-21$ & 43 \\
\hline Barangay Captain & 25 & 57 \\
\hline Length of service & 33 & \\
\hline$>$ mean & & \\
\hline$<$ mean & & \\
\hline Mean: 8.72 & & \\
\hline
\end{tabular}

Regarding the level of education, followed by respondents who completed secondary education (19\%) and primary education (3.4\%), the table indicates that the majority which is $77.6 \%$ had completed tertiary education. This indicates that education is still a necessary requirement for being a public servant.

Considering the number of politicians in the family, more than half $(55.2 \%)$ has only one politician in the family and almost half of the total number of respondents has 2 or 3 politicians (36.2\% and 8.6\%, respectively) in the family, , which is considered as members of a political dynasty. According to a recent study by the Ateneo School of Government, dynasties thrive under decentralization in the Philippines wherein almost $70 \%$ of the entire local government leaders will be dynastic by 2040 (Yusingco, 2017). With all 80 provinces littered with political families, $74 \%$ of the elected members of the House of Representatives came from such dynastic groups (Tadem and Tadem, 2015). This implies that our political system is almost run by dynastic families.

Liberal Party, the second dominant party in the Philippines, comprised the majority of the respondents, with $27.6 \%$. It is followed by PDP - Laban with $10.3 \%$ and independent and other political parties with $8.6 \%$. Prior to the EDSA I revolution, party politics dominated our political scenery, with the Liberal Party as the most dominant. The Liberal Party (LP) and Nacionalista Party (NP) "duopolized" the national landscape (Panganiban, 2016). The Liberal Party, the current political party, is a democratic-elitist party founded in 1946 and survived fourteen years of dormancy (Hays, 2015).

For the class of municipality where the respondents belong, $74.1 \%$ of them are from the third class. These respondents are officials of the municipalities except San Jose, a first-class comprising $25.9 \%$.

With regard to the position of the respondents, the councilor is undoubtedly the majority of the respondents with 46.6\%, and Mayor and SK Federation President being the last with both $3.4 \%$.

For the length of service, the majority (57\%) of the respondents has long political experience serving 9 years and longer, with a mean of 8.72 and range of 3 - 18 years. According to Tadem and Tadem (2015), political families and dynasties have enabled even local politicians to serve longer than others who don't. Furthermore, when they reach the limit of their term, the position will usually be occupied by someone in the family. This is the very concept of political clans and dynasties in the Philippines.

\subsection{Political Perspectives of the Respondents with Regard to Federalism}

The overall political perspective of the respondents with regard to Federalism is moderately favorable $($ mean $=2.98)$. In terms of its indicators, the highest is social issues (mean $=3.12$ ), followed by political issues $($ mean $=2.96)$, and the lowest is economic issues (mean $=2.86)$, all with a description of moderately favorable. 


\section{Table 3: The Political Perspective of the Respondents}

\begin{tabular}{l} 
Political Issues \\
\hline $\begin{array}{l}\text { A Federal Government is suitable to the political condition } \\
\text { of the Philippines. }\end{array}$
\end{tabular}

Federalism will most likely solve the problem of graft and corruption because members of the Parliament have executive and legislative duties, removing pork barrel and more accountability.

Federalization will create autonomous and self-reliant local government units.

Federalism will end the war and development problems in Mindanao brought by separatists' movements.

Federalism will improve governance by promoting the development of strong, disciplined, and program-oriented political parties.

\begin{tabular}{l}
\hline Total \\
\hline Economic Issues \\
\hline $\begin{array}{l}\text { Poverty in the countryside will be checked } \\
\text { if the federal system of government }\end{array}$ \\
The prevalence of graft and corruption in the government \\
discourages businessmen and investors.
\end{tabular}

Federalization guarantees an equitable distribution of funds and resources in the nation.

Granting local government units with the power to create money would lead to uncontrollable inflation.

Rural growth and development are given less emphasis in the current system of our government.

|

\begin{tabular}{|l|}
\hline Mean \\
\hline 3.17
\end{tabular}

\begin{tabular}{|c|c|}
\hline Range \\
\hline Moderately favorable \\
\hline
\end{tabular}

\begin{tabular}{|l|l|}
\hline 2.79 & Moderately favorable \\
\hline 3.34 & Moderately favorable \\
\hline
\end{tabular}

\begin{tabular}{|c|c|}
\hline 2.53 & Moderately favorable \\
\hline 2.93 & Moderately favorable \\
\hline 2.96 & Moderately favorable \\
\hline & \\
\hline & \\
\hline
\end{tabular}

\begin{tabular}{|c|c|c|}
\hline current system of our government. & 2.91 & Moderately favorable \\
\hline Total & 2.86 & Moderately favorable \\
\hline \multicolumn{3}{|l|}{ Social Issues } \\
\hline $\begin{array}{l}\text { Social awareness among Filipinos is a necessity } \\
\text { for a federal system of government. }\end{array}$ & 3.31 & Moderately favorable \\
\hline $\begin{array}{l}\text { Misconceptions about charter change hinder } \\
\text { Filipino people to accept federalization. }\end{array}$ & 3.36 & Moderately favorable \\
\hline $\begin{array}{l}\text { The Federal Republic will empower its citizens } \\
\text { by enabling them to raise their standard of living. }\end{array}$ & 2.93 & Moderately favorable \\
\hline $\begin{array}{l}\text { In Federalism, people's liberty will be protected } \\
\text { by the further dispersion of power in the } \\
\text { government and society. }\end{array}$ & 2.91 & Moderately favorable \\
\hline $\begin{array}{l}\text { Federalism will preserve and protect existing } \\
\text { languages and ethno-linguistic rights of people. }\end{array}$ & 3.07 & Moderately favorable \\
\hline Total & 3.12 & Moderately favorable \\
\hline Overall Political Perspective of the Respondents & 2.98 & Moderately favorable \\
\hline
\end{tabular}


In a Federal system of government, social consciousness must be recognized by Filipinos as crucial to their own good (Duron, 1992). This is manifested in the data gathering that most of the respondents agreed that social issues are really a concern in this charter change. This has also concurred in the responses in the item with the highest mean (mean $=3.36$ ) which is "misconceptions about charter change hinders Filipino people to accept federalization". It may readily be perceived that the shift to federalism will be met with much resistance from unitary system advocates as well as citizens who are used to the norm or present system of Local Government Units (Acosta, 2013).

The most important aspect of a federal system is that it recognizes that there are different types of political issues which need different types of institution to deal with them. Some affect only a local area; others are more widespread in their scope (Bautista et al., 2008). It is in these reasons that political perspectives in terms of political issues were studied by the researcher.

Political issues got the second-highest mean (mean $=2.98)$ among the indicators of political perspectives. The item with the highest (mean $=3.34$ ) is "federalization will create autonomous and self-reliant local government units." This is supported by the study of Duron (1992) wherein respondents agreed that federalization would cause a greater degree of decentralization for the local government units in the country.

The respondents' perception of economic issues garnered the lowest mean of 2.86 among the other indicators. The item with the highest mean (mean =3.09) is "federalization guarantees equitable distribution of funds and resources in the nation." This refutes the result of Duron (1992) that all his respondents disagreed that federalization scheme guarantees equitable resources in the nation. Still, this positively connotes that the respondents believed in federalism, especially fiscal federalism.

\subsection{Difference Between the Political Perspectives of the Respondents}

The following table shows the ANOVA analysis of the difference between the political perspectives of the respondents in terms of age. The indicators which have significant differences as to age are the perspectives on economic $(p=0.004)$ and social issues $(p=0.034)$.

Table 4: Difference Between the Perspectives of the Respondents in Terms of Age

\begin{tabular}{|l|c|c|c|}
\hline Indicators & $\boldsymbol{F}$ & Sig. & Interpretation \\
\hline Political Issues & 1.741 & 0.112 & Not Significant \\
\hline Economic Issues & 3.302 & 0.004 & Significant \\
\hline Social Issues & 2.314 & 0.034 & Significant \\
\hline
\end{tabular}

According to Kuotsu (2016), it is expected that age will have a positive effect on political opinion and views. He further stated that the older respondents presumably will be more politically knowledgeable than the younger respondents, because as people grow older they may have more exposure to politics which is often considered as an important source of political information. His findings supported the result of this study.

In terms of the respondents' perspectives on economic issues, the age group 20 -24 shows a significant difference in the age group 65-69 ( $p=0.007)$. However, the result is negative $(-0.750)$ so it indicates that the age group 65-69 has given a more favorable response when compared to the age group $20-24$ (Table 5).

Table 5: Post Hoc Test in Terms of Age

\begin{tabular}{|l|c|c|c|c|l|}
\hline \multicolumn{7}{|c|}{ Mean Difference } \\
\hline Dependent Variable & $(I)$ Age & $(J)$ Age & $(I-J)$ & Sig. & Interpretation \\
\hline Economic Issues & $20-24$ & $65-69$ & $-0.750^{*}$ & 0.007 & Significant \\
\hline Social Issues & $65-69$ & $70-74$ & $1.033^{*}$ & 0.003 & Significant \\
\hline
\end{tabular}

In terms of the respondents' perspective in social issues, the age group $65-69$ shows a significant difference in the age group $70-74(p=0.003)$. The analysis also shows a positive result $(1.033)$ indicating that the age group $65=69$ has given a more favorable response than those respondents in the age group $70-74$. 
Many researchers have conducted similar studies of political perspective in terms of sex. One particular is the study of Ahmed et al. (2014). According to their study, the level of political awareness among female students is comparatively low as compared to male respondents. Furthermore, a host of studies have shown that male adolescents have greater political knowledge than females (Furnham and Gunter, 1983). This is also supported by the study of Kurtbas (2015) that in terms of knowledge, women are more outside of the political area than men are. He also stated that women have not become politicized not only because of lower political interest but also because there is a well-rooted/practical sociopolitical culture in the society which asserts that politics is a "man's job".

The following table shows the ANOVA analysis to determine the difference between the respondents' political perspective when they are grouped according to their sex. The $t$-values are not significant since the $p$-values are more than 0.05 level of significance, political issues $(p=0.045)$. The $t$-values show the negative result in political issues $(-2.046)$, thus, females gave more favorable responses than men in terms of political issues (Table 6).

Table 6: Difference Between the Perspectives of the Respondents in Terms of Sex

\begin{tabular}{|l|c|c|c|}
\hline Indicators & $\boldsymbol{F}$ & Sig. & Interpretation \\
\hline Political Issues & -2.046 & 0.045 & Significant \\
\hline Economic Issues & -1.003 & 0.320 & Not Significant \\
\hline Social Issues & -1.208 & 0.232 & Not Significant \\
\hline
\end{tabular}

Education increases one's knowledge of politics; both by enhancing one's ability to acquire, organize and retain political information, and by increasing one's motivation to acquire such information (Kuotso, 2016).

In terms of the level of education, it is shown from the results of ANOVA that there is no significant difference between the perspectives of the respondents with regard to Federalism. The $f$-values are not significant since the $p$ values are higher than 0.05 level of significance. It means that the level of education of the respondents doesn't affect their responses. This means whether they are college graduate or attained a lower level of education, their perspective with federalism are basically the same (Table 7).

Table 7: Difference Between the Perspectives of the Respondents in Terms of the Level of Education

\begin{tabular}{|l|c|c|c|}
\hline Indicators & $\boldsymbol{F}$ & Sig. & Interpretation \\
\hline Political Issues & 0.838 & 0.438 & Not Significant \\
\hline Economic Issues & 3.003 & 0.058 & Not Significant \\
\hline Social Issues & 1.739 & 0.185 & Not Significant \\
\hline
\end{tabular}

Family plays a vital role in the engagement and political view of a person. According to Husaini et al. (2012), there are some roles involved such as the family in making the effective awareness of political aspects for students; parents should encourage their children to utilize the culture of intellectual since childhood and begin at their homes. Parents should emphasize the development of the landscape of educations integrity (informal learning) which occupies the series of life from various aspects especially in nationhood (politics).

Table 8 shows the one-way ANOVA analysis to determine the difference between the respondents' political perspective when they are grouped according to the number of politicians in the family. The $f$-values are not significant since the

Table 8: Difference Between the Perspectives of the Respondents in Terms of the Number of Politicians in the Family

\begin{tabular}{|l|c|c|c|}
\hline Indicators & $\boldsymbol{F}$ & Sig. & Interpretation \\
\hline Political Issues & 0.969 & 0.386 & Not Significant \\
\hline Economic Issues & 1.336 & 0.271 & Not Significant \\
\hline Social Issues & 0.429 & 0.653 & Not Significant \\
\hline
\end{tabular}


$p$-values are higher than 0.05 level of significance. The findings imply that whether they have other politician members in the family or not, it doesn't affect their perspective at all.

Political parties are important elements of a state wherein it provides candidates during elections. It has long been seen as a fundamental force shaping public opinion, and information about parties' positions on political (Slothuus, 2015). Furthermore, a political party is an inevitable factor in shaping Philippine Federal structure because their number, internal structure, ideology, leader's commitment to pluralism or unitary centralism, and actions are evidently related to the actual working of federalism (Ogunnoiki, 2017).

It is a fact that PDP Laban, the currently dominant political party in the Philippines, is vocal about their support on the advocacy of Federalism. It is even President Duterte who advocated this proposed charter change even before he was elected. Members of the same party are expected to advocate federalism because partisan often take the same policy position as their party (Slothuus, 2015). On the other hand, the opposition such as the Liberal Party has not yet signified its preference or resistance to it.

Table 9 shows the one-way ANOVA analysis to determine the difference between the respondents' political perspective when they are grouped according to their political party affiliations. The $f$-values are not significant since the $p$-values are higher than 0.05 level of significance. The findings imply that whether respondents are members of PDP Laban or Liberal Party or not, they have the same political perspectives.

Table 9: Difference Between the Perspectives of the Respondents in Terms of Political Party Affiliations

\begin{tabular}{|l|c|c|c|}
\hline Indicators & $\boldsymbol{F}$ & Sig. & Interpretation \\
\hline Political Issues & 0.458 & 0.714 & Not Significant \\
\hline Economic Issues & $0.344^{*}$ & 0.008 & Not Significant \\
\hline Social Issues & $0.416^{*}$ & 0.001 & Not Significant \\
\hline
\end{tabular}

Note: *Significant at the level $0.01(2$-tailed)

The findings supported the study of Kuotsu (2016) that political perspective seems to be important for being a member of a political party because in this study, independent officials and members of other parties aside from PDP Laban, the federalism proponent, have the different political perspective regarding Federalism, specifically on economic and social issues.

Table 10 shows the ANOVA analysis to determine the difference between the respondents' political perspective when grouped according to the class of municipality. The $t$-values are not significant since the $p$-values are higher than 0.05 level of significance, thus, there's no difference in the respondent's perspectives from first up to third class municipalities.

Table 10: Difference Between the Perspectives of the Respondents in Terms of the Class of Municipality

\begin{tabular}{|l|c|c|c|}
\hline Indicators & $\boldsymbol{F}$ & Sig. & Interpretation \\
\hline Political Issues & 0.721 & 0.474 & Not Significant \\
\hline Economic Issues & -0.613 & 0.543 & Not Significant \\
\hline Social Issues & 0.792 & 0.432 & Not Significant \\
\hline
\end{tabular}

Table 11: Difference Between the Perspectives of the Respondents in Terms of Position

\begin{tabular}{|l|c|c|c|}
\hline Indicators & $\boldsymbol{F}$ & Sig. & Interpretation \\
\hline Political Issues & 1.525 & 0.198 & Not Significant \\
\hline Economic Issues & 1.335 & 0.264 & Not Significant \\
\hline Social Issues & 0.887 & 0.497 & Not Significant \\
\hline
\end{tabular}


In terms of the positions of the respondents, it is shown from the results of ANOVA that there is no significant difference between the perspectives of the respondents with regard to Federalism. The $f$-values are not significant since the $p$-values are higher than 0.05 level of significance (Table 11).

According to Kuotsu (2016), it is held that those who are gainfully employed tend to have high levels of political interest and to be more knowledgeable about politics. He further added that this could be due to the fact that the occupation of a person is clearly related to the degree of his formal education. This occupation, when honed and is practiced all throughout his life, is expected to provide his knowledge and engagement due to exposure and participation.

Table 12 shows the ANOVA analysis to determine the difference between the respondents' political perspective when they are grouped according to their length of service. The $f$-values are not significant since the $p$-values are higher than 0.05 level of significance. The findings imply that new and senior employees' political perspective are not statistically different.

Table 12: Difference Between the Perspectives of the Respondents in Terms of Length of Service

\begin{tabular}{|l|c|c|c|}
\hline Indicators & $\boldsymbol{F}$ & Sig. & Interpretation \\
\hline Political Issues & 0.063 & 0.992 & Not Significant \\
\hline Economic Issues & 0.858 & 0.496 & Not Significant \\
\hline Social Issues & 0.291 & 0.882 & Not Significant \\
\hline
\end{tabular}

\section{Summary, Conclusion and Recommendations}

This chapter presents the summary, conclusions, and recommendations derived from the findings.

\section{Conclusion}

In the light of salient findings in the study, the following conclusions were derived:

1. The result shows that local government officials are middle-aged, male, and college graduate. In addition, they are the only politician in the family, members of the Liberal party, and councilors serving in the third class municipalities with short political experience.

2. The officials are "moderately perceptive" about the issues surrounding the proposed federal system of the Philippine government.

3. There is no significant difference with the political perspectives of the respondents in terms of sex, level of education, and the number of politicians.

\section{Recommendations}

After summarizing findings and drawing conclusions out of it, the recommendations of the researcher are as follows:

1. Future researchers may include or consider other types of respondents such as academicians, students, or the public even from other municipalities in the study of federalism.

2. A political perspective on economic issues is the indicator which respondents were less favorable that's why it is imperative that the current administration (DILG or LGUs) should conduct public forums and discussions to address issues especially on the prevalence of graft and corruption.

3. Age, sex, position, class of municipality and seminars and training attended of the respondents are the indicators which showed significant differences in the level of political awareness and political perspectives, thus, in order to address misconceptions and wrong impressions on the proposal considering these characteristics, DILG should reconsider these characteristics in their discussion or dissemination of information.

\section{References}

Abueva, J.V. (2005). Some Advantages of Federalism and Parliamentary Government for the Philippines. Retrieved February 16, 2020, from http://pcij.org/blog/wp-docs/Abueva-Federalism.pdf

Acosta, M.E. (2013). Federalism in the Philippines. Retrieved November 18, 2019 from https://www.scribd.com/doc/ 187139254/Federalism-in-the-Philippines 
Adamat, R.L. (2016). A Template on why and how Federalism is going to be implemented in the Philippines. Retrieved December 16, 2019 from https://www.youtube.com/watch?v=lewmg-zJkig

Balisacan, Hill., and Piza (2006). The Philippines and Regional Development Retrieved October 24, 2019 from https:// www.adb.org/sites/default/files/publication/159365/adbi-dynamic-regional-dev.pdf

Brillantes, A.B., Jr., Ilago, S.A., and Montes, R.N., Jr. (2009). The Future of Local Autonomy. Konrad Adenauer Stiftung. Salcedo Village, Makati City, Metro Manila.

Brillantes, A.B., Jr., (2016). Decentralization and Federalism in the Philippines: Lessons from Global Community. Retrieved May 16, 2018, from http://unpan1.un.org/intradoc/groups/public/documents/EROPA/UNPAN032065.pdf

DILG reports resources (2017). Retrieved from http://www.dilg.gov.ph/PDF_File/reports_resources/dilg-reports-resources2017323_186ace8e39.pdf

Duron, J.F. (1992). Federalism: An Alternative System for the Philippines. Retrieved from https://pdfs.semanticscholar.org/ acd6/220766d013b05cefe8f2bdc485115a010b04.pdf

Furnham., and Gunter. (1983). Political knowledge and awareness in adolescents. Retrieved November 15, 2019 from https://www.ncbi.nlm.nih.gov/pubmed/6668375

Husaini et al. (2012). Political awareness among UTP student; an effective tool to empower nation. Retrieved November 15, 2019 from https://www.academia.edu/2578471/Political_awareness_among_UTP_studen

t_an_effective_tool_to_empower_nation

Kurtbas, I. (2015). The Factors Influencing Voting Preferences in Local Elections: An Empirical Study. Retrieved November 15, 2019 from http://dx.doi.org/10.15640/jasps.v3n2a6

Malaya, J.E. (2017). The PDPLaban Model of PH Federalism: An Executive Summary. Retrieved from http://www.iag.org.ph/ index.php/blog/1503-the-pdp-laban-model-of-ph-federalism-an-executive-summary

Manahan, J.A.R. (2018). Only 5 regions ready for Federalism: Study. Retrieved from https://varsitarian.net/specialreports/20181003/Only-5-regions-ready-for-federalism-study

Miral, R.E.M., Jr., (2017). Federalism: Prospects for the Philippines. Retrieved from https://pidswebs.pids.gov.ph/CDN/ NEWS/pidsdps1729.pdf

Ogunnoiki, A.O. (2017). Federalism as a Political Ideology and System of Government: The Theoretical Perspectives. Retrieved from http://www.ijaar.org/articles/Volume3-Number9/Social-Management-Sciences/ijaar-sms-v3n9sep 17-p7.pdf

Philippine Institute for Development Studies. (2006). Economic Issue of the Day. Retrieved from https://dirp4.pids.gov.ph/ ris/eid/pidseid0602.pdf

Philippine Statistics Authority. (2015). Poverty incidence among Filipinos registered at 21.6\% in 2015. Retrieved January 16, 2020 from https://psa.gov.ph/content/poverty-incidence-among-filipinos-registered-216-2015-psa

Pimentel, A., Jr. (2002). Why Adopt the Federal System of Government? Retrieved January 16, 2020, from http:// www.nenepimentel.org/speeches/

Pimentel, A., Jr. (2001). Federalizing the Republic: the ultimate basis for a just and lasting peace in central and southern Mindanao. Retrieved from http://www.nenepimentel.org/speeches/

Slothuus, R. (2015). Assessing the Influence of Political Parties on Public Opinion: The Challenge from Pretreatment Effects. Retrieved November 15, 2019 from http://dx.doi.org/10.1080/10584609.2015.1052892

USA Online. (n.d.). Government State and Local Government (ND). Retrieved from http://www.theusaonline.com/ government/state-local-government.htm

Cite this article as: Melchor Padilla Dioso and Wenceslao M. Paguia (2021). Political perspective on the proposed federal system of government of local government officials in samarica, occidental mindoro. International J ournal of Political Scienceand Public A dministration, 1(2), 1-12. doi : 10.51483/ IJPSPA.1.2.2021.1-12. 